\title{
Pulmonary Embolism in the ICU
}

Editors

BHARAT AWSARE

MICHAEL BARAM

GENO MERLI

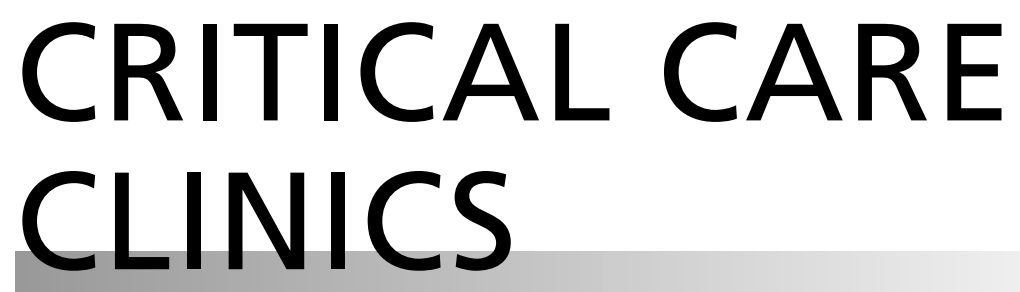

www.criticalcare.theclinics.com

Consulting Editor

JOHN A. KELLUM

July $2020 \bullet$ Volume 36 • Number 3 